Cita bibliográfica: Amaya Molinar, C.M., Sosa Ferreira, A.P, Ochoa-Llamas, I. y Moncada Jiménez, P. (2017). The perception of destination competitiveness by tourists. Investigaciones Turísticas (14), pp. 1-20. https://dx.doi.org/10.14461/INTURI2017.14.01

\title{
The perception of destination competitiveness by tourists
}

\section{La percepción del turista sobre la competitividad de destinos turísticos}

Carlos Mario Amaya-Molinar. Universidad de Colima, México. cmamaya@ucol.mx Ana Pricila Sosa-Ferreira. Universidad del Caribe, México.psosa@ucaribe.edu.mx Ileana Ochoa-Llamas. Universidad de Colima, México.ileana8a@ucol.mx Pedro Moncada-Jiménez. Universidad del Caribe, México.pmoncada@ucaribe.edu.mx

\section{ABSTRACT}

Based on a review of the academic literature this study identifies some of the most frequently mentioned factors and indicators in the field of a tourist destination competitiveness to design a survey subsequently conducted among tourists in Cancun, México. An exploratory factor analysis was performed with the collected data; the result was the reduction from twelve competitiveness factors most commonly mentioned in academic literature to five: Destination marketing and attractions, Destination management and security, Cultural heritage, ICT adoption and Transportation. The study confirms the contributions of several works on the subject while some others common assumptions found in the literature could not be corroborated.

Keywords: Destination, competitiveness, tourist, image, exploratory factor

\section{RESUMEN}

A partir de una revisión de la literatura académica, el trabajo identifica algunos de los factores e indicadores más citados en el campo de estudio de la competitividad de destinos turísticos para diseñar una encuesta realizada entre turistas en Cancún, México. Se realizó un análisis factorial exploratorio con los datos recogidos, obteniendo como resultado la reducción de doce factores de competitividad mencionados con mayor frecuencia en la literatura académica a cinco: Marketing de destino y atracciones, Gestión y seguridad de los destinos, Patrimonio cultural, Adopción de las TIC y Transporte. El estudio confirma las contribuciones de varias obras sobre el tema, aunque algunos de los supuestos más comunes en la literatura del tema no fueron corroborados.

Palabras clave: destino, competitividad, turismo, imagen, análisis exploratorio, factor.

\section{INTRODUCTION}

Academic, political, technological and business discourses frequently include the term competitiveness applied in studies on countries, regions, industries, and companies. 128 institutional and academic publications on the subject were initially gathered; after a preliminary review, 37 works were retained to be included in the study. Most of the 
theoretical tourist competitiveness models analyzed provide little academic attention toward the main actor in the tourism system: the tourist. Important parts of the examined studies stand on statistics supplied by national and international agencies or in surveys and interviews with industry officials, executives, graduate students, and scholars. This study is an exploratory research performed to advance the understanding of the direct perception of tourism destination's competitiveness by visitors. Utilizing an exploratory factor analysis, the work has sought to determine if domestic tourists visiting a destination can perceive some of the main factors of tourism competitiveness mentioned in academic literature. A sample of Mexican tourists answered a survey, as crucial stakeholders in the tourism system in Cancun, a major national sun and sea destination.

The study can be replicated in other destinations and with international tourists to confirm its results; it is advisable to investigate the perception of competitiveness by other stakeholders not yet considered in studies in this field, like workers in the tourism industry and host population.

The study confirms the importa7nce of policies and regulations, air transport infrastructure, cultural resources and coverage of information and communications technologies as factors influencing the competitiveness of tourist destinations.

\section{LITERATURE REVIEW}

\subsection{Concepts and models of tourism competitiveness}

Historically, initial approaches to competitiveness in academia go back to the XVII century (Cho and Moon, 2013). More recently, the World Economic Forum (1994: 18) defines competitiveness as "the degree to which a nation can, under free trade and fair market conditions, produce goods and services which meet the test of international markets, while simultaneously maintaining and expanding the real income of its people over the long-term." Definitions of tourism competitiveness found in the academic literature are very diverse; some authors use very simplistic definitions, others don't even define it; quotes to the works of Porter $(1993,1998)$ and Ritchie and Crouch $(1993,1999,2005)$ are very common.

Enright and Newton (2005:340) propose a simple concept of destination competitiveness: "A tourist destination is competitive if it can attract and satisfy potential tourists". Cracolici \& Nijkamp (2008) define competitiveness as the qualitative and quantitative superiority of a unit, company or territory above all competitors. To Croes \& Rivera (2010), competitiveness influences the quality of life of residents at the destination, assuming that GDP income per capita is a proxy of quality of life; Zhang \& Jensen (2007) and Li \& Huang (2010) examine competitiveness analyzing temporary fluctuations in the flows of tourists. Claver-Cortés et al. (2007) assume that the competitiveness' level of a destination depends on the efficiency of the companies operating there. The Travel \& Tourism Competitiveness Report 2013 (Blanke \& Chiesa, 2013) measures the factors and policies that make tourism development an attractive industry in different countries, but does not define a concept; the index is composed of 3 subindexes and 14 pillars.

The strength of the theoretical model of Ritchie and Crouch (2005) makes it the most cited in the academic literature of tourism; their definition emphasizes the environmental, economic and social sustainability of tourist operation, as well as the satisfaction of visitors. 
The model incorporates Porter's comparative and competitive advantages (1998), places the destination in its macroenvironment, relating it to their microenvironment and considers five basic factors, composed, in turn, by a set of 36 sub-factors influencing the competitiveness of a destination. While this model has a sound theoretical basis, it is very difficult to measure the 436 quantitative and qualitative dimensions of the phenomenon proposed to determine destination competitiveness.

\subsection{Types of studies of tourism competitiveness}

A significant proportion of the works on competitiveness consulted uses an economic approach (Mangion et al., 2012; Vu \& Turner, 2011; Zhang \& Jensen; 2007). Several studies (Barros et al., 2011; Claver-Cortes et al., 2007; Cracolici et al., 2008; Croes \& Rivera, 2010; Molina-Azorin et al., 2010) analyze the efficiency in the operation of tourist destinations, an approach intrinsically linked with the economic aspect. Another important group of works establishes theoretical models of tourism competitiveness (Blanke \& Chiesa, 2013; Dwyer \& Kim, 2003; Ritchie \& Crouch, 2005). Some of these models frequently are the basis for other works; for example, the studies of Mazanec et al. (2007); Webster \& Ivanov (2014); Wu et al. (2012) use the tourism competitiveness paradigm developed by Blanke \& Chiesa (2013) for the World Economic Forum.

Some academic works search an appropriate method to study tourism competitiveness (Botti \& Peypoch, 2013; Huang \& Peng, 2012; Medina-Muñoz et al., 2013; Zhang et al., 2011). Another set of papers focus on the management and marketing of tourist destinations (Andrades-Caldito et al., 2013; Buhalis, 2000; Go \& Govers, 2010; Pike \& Mason, 2010). For Faulkner et al. (1999) and Enright \& Newton $(2004,2005)$ the attractions are the center of attention, while only two works focus on the relationship between tourism competitiveness and sustainability: Hassan (2000) and Huybers \& Bennett (2003).

\subsection{Methodologies employed in the study of competitiveness}

The methodologies employed in the academic works on competitiveness reviewed are even more diverse than the types of approaches. An important part of the analyzed studies (42\%) derives from statistics supplied by national and international agencies, especially those focused on economics subjects and in the World Economic Forum's index. $10 \%$ of works do not provide statistical or empirical data, including some of the theoretical models most quoted by other researchers, like Ritchie \& Crouch (2005) and Dwyer \& Kim (2003). Regarding the $48 \%$ of works with empirical studies, $38 \%$ utilize surveys; the rest use qualitative methods. Only eight studies (17\%) consider perceptions of consumers and tourists; the rest of works with empirical study take into account perceptions of stakeholders, industry executives or people with relatively high educational levels: travel agents, hotel managers, executives and officials from the industry, academics, postgraduate students and administrators of destination management offices, among others.

While some of the theoretical models of competitiveness most quoted in the literature mention the well-being of the community and stakeholders, virtually none of the consulted works considers the point of view of the residents. Therefore, the majority of the consulted works provides little academic attention towards tourists, host population and the large base of workers of the tourism industry; that is, to the vast majority of the stakeholders involved in the operation of the industry. Regarding the unit of study, $52 \%$ of 
the works examine a region or city, $46 \%$ analyze countries and $2 \%$ do not specify; in this study, we analyze the destination as a city.

\subsection{Measures of tourism competitiveness}

The great diversity of approaches between the revised works makes it difficult to define what the dependent and independent variables of theoretical models are. Nevertheless, we identified a set of measurements to consider as independent variables or results of competitiveness in tourist destinations. The indicators of tourism competitiveness results usually are dynamically registered tracking its temporary evolution and comparing the outcomes with competing destinations, by the very nature of the subject. Several of these indicators refer to the number of visitors and data relating to the hotel industry operation and its efficiency, such as the occupation rate, length of stay and revenue per available room (Barros et al., 2011; Claver-Cortes et al., 2007; Cracolici et al., 2008).

Exploring beyond the number of visitors and their stay, the analysis of the expenditure of tourists is considered relevant in this field, as well as its economic impact on the destination and the population's well-being (Croes, 2010; Ritchie \& Crouch, 2005; Webster \& Ivanov; 2014). Some standard marketing measures are also important, such as the evolving of market share or, with more depth in the field of consumer behavior, information about quality, satisfaction and behavioral intentions of tourists (Li \& Huang, 2010; Pike \& Mason, 2010; Mazanec et al., 2007).

\subsection{Factors of tourism competitiveness}

The literature review presents a large number of factors that the competitiveness of tourist destinations. Table 1 presents the 12 most frequently mentioned factors in 27 academic and institutional papers.

The study of competitiveness of tourist destinations is similar to the investigation of the destination image. Pike (2002) and Gallarza et al. (2002) reviewed in depth 142 and 65 works on this topic, respectively. They highlighted the variety of approaches, objects, subjects, and methods used to identify the most frequently analyzed attributes of the destination image. Some of the works on competitiveness reviewed include dimensions of destination image's field. Gallarza et al. (2002) underline that researchers classified the destinations according to the aims of the study. 
Table 1. Factors determining the competitiveness of tourist destinations

\begin{tabular}{|c|c|c|c|c|c|c|c|c|c|c|c|c|c|c|}
\hline \multirow[b]{3}{*}{$\mathbf{N}^{\circ}$} & \multirow[b]{3}{*}{ AUTHORS } & \multicolumn{13}{|c|}{ FACTORS } \\
\hline & & & 2 & 3 & 4 & 5 & 6 & 7 & 8 & 9 & 10 & 11 & 12 & \\
\hline & & 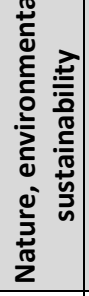 & 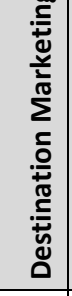 & 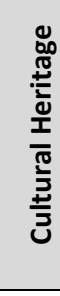 & 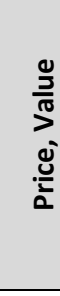 & 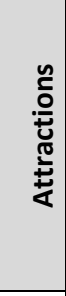 & 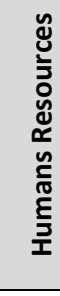 & 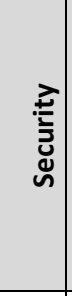 & 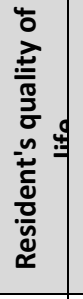 & 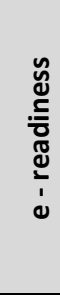 & 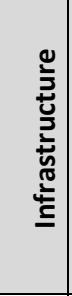 & $\begin{array}{l}\frac{t}{0} \\
\frac{0}{n} \\
\frac{c}{\pi} \\
\stackrel{5}{*}\end{array}$ & 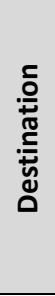 & 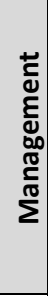 \\
\hline 1 & Andrades-Caldito et al. (2012) & $\mathrm{X}$ & & $x$ & $\mathrm{X}$ & $\mathrm{X}$ & & $\mathrm{X}$ & & & & $x$ & & \\
\hline 2 & Barros et al. (2011) & $\mathrm{x}$ & $\mathrm{X}$ & $x$ & & $\mathrm{X}$ & & & & & & & & \\
\hline 3 & Blanke \& Chiesa (2013) & $x$ & & $\mathrm{X}$ & $\mathrm{X}$ & $\mathrm{X}$ & $x$ & $\mathrm{X}$ & & $x$ & & $\mathrm{X}$ & & \\
\hline 4 & Bornhorst et al. (2010) & & $x$ & & & $\mathrm{X}$ & & & & & $\mathrm{X}$ & & $x$ & \\
\hline 5 & Caber et al. (2012) & $\mathrm{x}$ & $\mathrm{X}$ & $\mathrm{X}$ & $X$ & $X$ & & $\mathrm{X}$ & & & & $X$ & & \\
\hline 6 & Carmichael (2002) & & $\mathrm{X}$ & $\mathrm{X}$ & & & & & & & $\mathrm{X}$ & & & \\
\hline 7 & Claver et al. (2007) & $\mathrm{x}$ & $\mathrm{X}$ & & $X$ & & $x$ & & & $X$ & & & & \\
\hline 8 & Cracolici \& Nijkamp (2008) & $x$ & & & & $\mathrm{X}$ & & $\mathrm{X}$ & & & & & & \\
\hline 9 & Cracolici et al. (2008) & & & $x$ & & & $x$ & & & & & & & \\
\hline 10 & Crouch (2010) & $x$ & $x$ & $x$ & $\mathrm{X}$ & $x$ & & $\mathrm{X}$ & & & & & & \\
\hline 11 & Dupeyras \& McCallum, 2013 & & $x$ & $x$ & $x$ & & $x$ & & & & $\mathrm{X}$ & & & \\
\hline 12 & Dwyer \& Kim (2003) & $x$ & $x$ & $x$ & & $\mathrm{X}$ & & & $x$ & & & & $x$ & \\
\hline 13 & Dwyer et al. (2012) & $x$ & $x$ & & & & $x$ & & & & & & $x$ & \\
\hline 14 & Enright \& Newton $(2004,2005)$ & $x$ & & $x$ & & $\mathrm{X}$ & $x$ & $\mathrm{X}$ & $x$ & $x$ & & $x$ & $x$ & \\
\hline 15 & Faulkner et al. (1999) & & & & & $X$ & & & & & $x$ & & & \\
\hline 16 & Go \& Govers (2010) & $x$ & $x$ & & & & $x$ & & $x$ & & & & $x$ & \\
\hline 17 & Gomezelj \& Mihalic (2008) & $\mathrm{x}$ & $\mathrm{X}$ & & $x$ & $\mathrm{X}$ & $x$ & $\mathrm{X}$ & & & & & & \\
\hline 18 & Gooroochurn \& Sugiyarto (2005 & $\mathrm{x}$ & & & $\mathrm{X}$ & & $\mathrm{X}$ & & $\mathrm{X}$ & $x$ & & & & \\
\hline 19 & Hassan (2000) & $\mathrm{x}$ & $x$ & & & & & $\mathrm{X}$ & & & $\mathrm{X}$ & & $x$ & \\
\hline 20 & Huang \& Peng (2012) & $\mathrm{x}$ & $x$ & $x$ & $x$ & $\mathrm{X}$ & & & $\mathrm{X}$ & & & $\mathrm{X}$ & & \\
\hline 21 & Huybers \& Bennett (2003) & $\mathrm{x}$ & $\mathrm{X}$ & & $\mathrm{X}$ & & & & & & & & & \\
\hline 22 & Mazanec et al. (2007) & $\mathrm{x}$ & & $x$ & $x$ & & $x$ & & $\mathrm{X}$ & $x$ & & & & \\
\hline 23 & Pike \& Mason (2010) & & $\mathrm{X}$ & & & & & & & & & & & \\
\hline 24 & Rodrigues \& Carrasqueira (2011) & $\mathrm{x}$ & & $\mathrm{x}$ & $\mathrm{X}$ & & & $\mathrm{X}$ & $\mathrm{X}$ & $x$ & & & & \\
\hline 25 & Webster \& Ivanov (2014) & & & & & & & & $x$ & & $x$ & & & \\
\hline 26 & Wu et al. (2012) & $x$ & & $x$ & $x$ & & $x$ & $x$ & & $x$ & & $x$ & & \\
\hline 27 & Zhang et al. (2011) & $x$ & & & & $x$ & & & & & $x$ & & & \\
\hline & TOTAL & 20 & 15 & 14 & 13 & 13 & 11 & 10 & 8 & 7 & 7 & 6 & 6 & \\
\hline
\end{tabular}


In this study, the academic literature was reviewed to identify the factors of competitiveness of tourist destinations most frequently mentioned, like Pike (2002) and Gallarza et al. (2002) did on destination image. Likewise, these components consider different approaches, methods, objects, and subjects; therefore, the factors used in this work are a generalization. In addition, this research includes an empirical study, while the papers on destination image previously mentioned a focus on literature review.

Draws attention the factor "Nature, environmental sustainability", the most frequently quoted in the mentioned works and surprisingly the least studied and more complex to research. At the opposite extreme, we have less mentioned factors, like human resources, adoption of information and communication technologies and destination management, although the studies from Enright \& Newton $(2004,2005)$ and Wu et al. (2012) demonstrate their influence on competitiveness.

\section{METHODOLOGY AND EMPIRICAL STUDY}

Beyond the studies based on indexes and indirect measurements, this work utilizes an exploratory factor analysis to find out if some of the main factors of tourism competitiveness mentioned in academic literature can be perceived by tourists visiting a destination. It is not the purpose of this study to identify the degree of influence of identified components in the levels of competitiveness, but only find out if a crucial stakeholder of the tourism system, the domestic tourist, is able to perceive them.

Among the few studies on tourist competitiveness based on surveys answered directly by visitors are the works of Pike \& Mason (2010) and Caber et al. (2012), which have in common that both utilize Importance-Performance Analysis methodology. Carmichael (2002) interviewed visitors directly in a cultural exhibition at an art gallery while Botti \& Peypoch (2013), Cracolici \& Nijkamp (2008) and Andrades-Caldito et al. (2012) employed data generated in surveys provided by official institutions; none of these works considers an exploratory factor analysis.

\subsection{Survey design}

Since there is no consensus among researchers to define a univocal concept of tourism competitiveness and it is not likely that common visitors have knowledge of any of them, it was not considered appropriate to ask directly for tourists surveyed about their perception of the issue; instead, they were told the questionnaire was designed to obtain their views on some aspects of the destination. The survey does not refer directly to tourism competitiveness, but retrieves information on the factors most frequently mentioned in the academic literature (table 2); a set of items was designed to represent each of them.

Table 2: Subjects corresponding with competitiveness factors

\begin{tabular}{|c|c|}
\hline FACTORS & SUBJECT \\
\hline $\begin{array}{c}\text { Nature, environmental } \\
\text { sustainability }\end{array}$ & Nature's beauty and conservation, absence of pollution. \\
\hline Destination Marketing & Considers consumer behavior, destination image, branding. \\
\hline Cultural Heritage & History, museums, archeology, traditions, public art, etc. \\
\hline Price, Value & Benefits received in exchange for money and travel efforts. \\
\hline
\end{tabular}




\begin{tabular}{|c|c|}
\hline Attractions & $\begin{array}{l}\text { Quality, diversity, and interest of tourist attractions and } \\
\text { recreation offer. }\end{array}$ \\
\hline Humans Resources & Qualification and training of staff in contact with visitors. \\
\hline Security & Feeling of security in the destination. \\
\hline Resident's quality of life & Perception of welfare and prosperity of host population. \\
\hline$E$ - readiness & $\begin{array}{l}\text { Coverage and adoption of information and communication } \\
\text { technologies in the destination. }\end{array}$ \\
\hline Infrastructure & $\begin{array}{l}\text { Public and urban services, institutions, facilities, } \\
\text { transportation terminals, etc. }\end{array}$ \\
\hline Transportation & $\begin{array}{l}\text { Transportation services to and into the destination: bus, } \\
\text { taxis, ferryboats, air carriers, etc. }\end{array}$ \\
\hline Destination Management & $\begin{array}{l}\text { The organization, cooperation, priority, and stability in } \\
\text { tourist operations at the destination. }\end{array}$ \\
\hline
\end{tabular}

The questionnaire has two parts: a first one based on the respondents' profile gathers information on socio-demographic data; the second section presents items on the factors of competitiveness, using Likert scales of 5 points.

\subsection{The tourist destination case study}

The empirical study was conducted in Cancun, Quintana Roo, the main Sun and beach destination of Mexico, with the country's most competitive tourist industry; it is located on the Caribbean Sea, northeast of the Yucatan peninsula. It is a typical third generation's tourist destination (Claver-Cortes et al., 2007), developed by the Bank of Mexico to generate foreign currency. Since the decade of the 1970's, this destination has been the powerhouse of economic development for the Yucatan peninsula. Table 3 shows how Cancun can be considered competitive in some indicators proposed in the academic literature, in absolute terms, in trends and socio-demographic indexes; its outcomes in a number of visitors and occupation rate show positive evolution, with outstanding results in terms of length of stay, tourism receipts and lodging offer.

Table 3: Cancun's basic tourist data

\begin{tabular}{|c|c|c|c|c|}
\hline Visitors & $\Delta \% 2012-2013$ & Occupation Rate \% & $\Delta \%$ 2012-2013 & $\begin{array}{c}\text { Length } \\
\text { of Stay (Days) }\end{array}$ \\
\hline $4,093,942$ & 12.4 & 76.8 & 4.3 & 5.1 \\
\hline $\begin{array}{c}\text { Tourism Receipts US } \\
\text { Millions }\end{array}$ & $\Delta \%$ 2012-2013 & $\begin{array}{c}\text { Average } \\
\text { Expenditure per } \\
\text { tourist (U\$D) }\end{array}$ & Hotels & Rooms \\
\hline $4,348.78$ & 16.1 & 1,062 & 145 & 30,608 \\
\hline
\end{tabular}

Source: DATATUR (2014), Gobierno de Quintana Roo (2014). 


\subsection{Sample and profile of respondents}

250 questionnaires were applied to domestic tourists with a convenience sampling procedure; students and professors from the University of the Caribbean applied the survey in August of 2014. Table 4 presents the demographic information of the polled population; the sample tends to concentrate in young and middle-aged individuals, with significant proportions of employees and self-employed, higher education in undergraduate and graduate levels and with income higher than the national average. The profile of respondents might be explained considering that Cancun is not an affordable destination for Mexicans,-since most visitors must fly to get there.

Table 4: Socio-demographic characteristics of the sample

\begin{tabular}{|c|c|c|c|c|c|}
\hline Gender & $\%$ & Age & $\%$ & Occupation & $\%$ \\
\hline Male & 51.4 & $18-24$ & 20.4 & Housewife & 2.8 \\
\hline \multirow[t]{2}{*}{ Female } & 48.6 & $25-34$ & 24.1 & Employee & 46.6 \\
\hline & 100 & $35-44$ & 31.1 & Self Employed & 27.9 \\
\hline Education & $\%$ & $45-54$ & 16.6 & Student & 14.6 \\
\hline No schooling & 2.1 & $55-64$ & 6.2 & Retired & 6.3 \\
\hline Basic Studies & 3.0 & & 100 & Others & 1.8 \\
\hline High School & 20.6 & Income & $\%$ & & 100 \\
\hline $\begin{array}{l}\text { Technical } \\
\text { Studies }\end{array}$ & 17.3 & Below national average & 21.4 & & \\
\hline Bachelor & 45.1 & $\begin{array}{l}\text { On the range of national } \\
\text { average }\end{array}$ & 52.2 & & \\
\hline \multirow[t]{2}{*}{ Postgraduate } & 11.9 & $\begin{array}{l}\begin{array}{l}\text { Above the national } \\
\text { average }\end{array} \\
\end{array}$ & 26.4 & & \\
\hline & 100 & & 100 & & \\
\hline
\end{tabular}

Own elaboration.

Regarding the sample, in Exploratory Factor Analysis it is generally recommended a minimum ratio of 10 surveys per item; in this study, there are 250 for 44 items, a ratio of 5.68 for the item; nevertheless, studies on the methodology show that sample size might be determined by the nature of data: if data is strong, a smaller sample can be used; strong means high commonalities, no cross-loadings and several variables loading firmly on each factor (MacCallum et al., 1999).

In social sciences, commonalities between 0.40 and 0.70 are considered acceptable (Velicer \& Jackson, 1990); the smallest dimension of commonality obtained in the data was 0.449, for item TRA3, "Quality of local transport system". Tabachnick \& Fidell (2012) consider 0.32 is the lowest load factor to accept a variable; in the present survey, the lesser load (0.428) was registered in item DM3, "Importance of tourism in the destination", also with the second smaller magnitude for a commonality, 0.494. Regarding the number of variables, a factor comprising less than three items is considered weak (Osborne \& Costello, 2005); all the factors retained in this study have at least three items, being the case of Information and Communications Technology (ICT) and Transport (TRA) (Table 6). 


\subsection{Exploratory Factor Analysis}

The literature review provided a large number of factors and indicators of tourism competitiveness, varying according to the approaches adopted by different authors; considering this, it was decided to adopt the Exploratory Factor Analysis method to reduce data and find the underlying structure within the broad set of variables. Hair et al. (2006) define factors as homogeneous groups formed with variables solidly correlated to each other and independent from the rest; this procedure can identify a minimum of dimensions able to explain much material contained in their data, simplifies and exposes the internal structure, delivering the same information with fewer aspects.

There are several methods for exploratory factor analysis; Principal Component Analysis and Varimax rotation are some of the techniques most commonly used in this type of methodology; however, they cannot be considered an obligatory standard for all the studies in its kind; some authors claim they are not the best option available, considering that the exploratory factor analysis is precisely that, a probing tool, not designed to test hypotheses or draw statistical inferences. Considering rotations, its essential purpose is to visualize clearly and simply the load factors and their grouping (Finch, 2006; Osborne, 2015); regarding this particular work, the Promax rotation is the procedure that functioned the best to visualize the factors included in the research.

To perform the exploratory factor analysis in this study, the data collected through surveys were processed with the software SPSS 22, applying the method of Maximum Likelihood with Promax rotation and extracting the Cronbach's alpha coefficient as an indicator of reliability with a minimum threshold of 0.7 (De Vellis, 2011); with a couple of exceptions, the items with a minimal load of 0.50 were kept, as well as factors with the lowest Eigenvalue of 1 and explanation of the variance with minimum level of $60 \%$ (table 6). Also included were the sphericity test of Bartlett with significance $p<.05$ and a KayserMeyer-Olkin value of 0.6 or more to confirm the adequacy of the sample (Tabachnick \& Fidell, 2012).

From twelve factors related to tourist destination's competitiveness proposed originally, five were deleted along with the Exploratory Factor Analysis process. The perception of competitiveness by tourists presented a substantial reduction: only 5 were retained (table 5). Although it must be remarked that 2 out of those factors apparently vanished actually persisted regrouped with others; such is the case of Attractions and Security, which reassembled with Destination Marketing and Destination Management, respectively; factors marked with * regroup with others, while aspects labeled with ** disappear. Table 7 shows the adequacy of sampling with the Kaiser-Meyer-Olkin measures, as well as the significance test of Bartlett and the appropriate explanation of variance, with $63.90 \%$. In chart 1, the scree plot shows the 5 factors with eigenvalues above 1 . 
Table 5: Reduction of tourism competitiveness factors perceived by tourists

\begin{tabular}{|c|c|c|c|c|c|}
\hline \multicolumn{3}{|c|}{ Initial } & \multicolumn{3}{|c|}{ Final } \\
\hline \multicolumn{2}{|c|}{ Factors proposed in literature } & \multirow{2}{*}{$\begin{array}{c}\text { Items } \\
3\end{array}$} & \multicolumn{2}{|r|}{ New factors } & \multirow{2}{*}{$\begin{array}{c}\text { Items } \\
11\end{array}$} \\
\hline 1 & Nature, sustainability * & & 1 & Destination marketing and attractions & \\
\hline 2 & Destination marketing * & 7 & 2 & Destination management and security & 7 \\
\hline 3 & Cultural heritage & 4 & 3 & Cultural heritage & 4 \\
\hline 4 & Price, value $* *$ & 3 & 4 & ICT adoption & 3 \\
\hline 5 & Attractions * & 4 & 5 & Transportation & 3 \\
\hline 6 & Human Resources ** & 3 & & TOTAL & 28 \\
\hline 7 & Security * & 3 & & & \\
\hline 8 & Residents quality of life $* *$ & 3 & & & \\
\hline 9 & ICT adoption & 3 & & & \\
\hline 10 & Infrastructure ** & 3 & & & \\
\hline 11 & Transportation & 3 & & & \\
\hline 12 & Destination management * & 4 & & & \\
\hline & TOTAL & 44 & & & \\
\hline
\end{tabular}

Table 6: Factors and items on perception of tourism competitiveness preserved

\begin{tabular}{|c|c|c|c|c|c|c|c|c|}
\hline \multirow{2}{*}{\multicolumn{2}{|c|}{ ITEMS }} & \multicolumn{5}{|c|}{ COMPONENT } & $\begin{array}{c}\text { Cronbach's } \\
\text { Alpha }\end{array}$ & \multirow[t]{2}{*}{ Commonalities } \\
\hline & & \multirow{2}{*}{$\frac{1}{.874}$} & 2 & 3 & 4 & 5 & .954 & \\
\hline IMA3 & Positive destination image & & & & & & .940 & 0.738 \\
\hline IMA4 & Expectations prior to the visit met. & .811 & & & & & & 0.785 \\
\hline IMA2 & Quality of visit experience. & .787 & & & & & & 0.694 \\
\hline NAT1 & Region's natural beauty & .779 & & & & & & 0.589 \\
\hline IMA1 & Destination brand awareness & .775 & & & & & & 0.571 \\
\hline IMA7 & Positive word of mouth & .771 & & & & & & 0.632 \\
\hline IMA5 & Preference for the destination & .736 & & & & & & 0.623 \\
\hline IMA6 & Intention to return & .726 & & & & & & 0.612 \\
\hline ATR3 & Variety of tours & .654 & & & & & & 0.548 \\
\hline ATR1 & Quality of attractions & .617 & & & & & & 0.522 \\
\hline ATR4 & Variety of recreation offer & .520 & & & & & & 0.592 \\
\hline \multirow{2}{*}{\multicolumn{2}{|c|}{ Eigenvalue: 12.781}} & \multicolumn{5}{|c|}{ \% of Variance Explained: 45.65} & & \\
\hline & & \multicolumn{5}{|c|}{ \% Cumulative variance: 45.65} & & \\
\hline SEC2 & Trustworthiness of local population & & .866 & & & & .922 & 0.679 \\
\hline DM4 & Political stability in the destination. & & .822 & & & & & 0.760 \\
\hline SEC3 & Positive conditions of hygiene & & .808 & & & & & 0.713 \\
\hline DM2 & Respect for laws and regulations & & .758 & & & & & 0.605 \\
\hline SEC1 & Feeling of safety & & .753 & & & & & 0.679 \\
\hline DM1 & $\begin{array}{l}\text { Cooperation among organizations to } \\
\text { foster tourism }\end{array}$ & & .731 & & & & & 0.677 \\
\hline DM3 & $\begin{array}{l}\text { Importance of tourism in the } \\
\text { destination }\end{array}$ & & & & & & & 0.494 \\
\hline \multirow{2}{*}{\multicolumn{2}{|c|}{ Eigenvalue: 2.253}} & \multicolumn{5}{|c|}{ \% of Variance Explained: 8.045} & & \\
\hline & & \multicolumn{5}{|c|}{ \% Cumulative variance: 53.69} & & \\
\hline HER1 & $\begin{array}{l}\text { Value of destination's cultural } \\
\text { heritage }\end{array}$ & & & .820 & & & .866 & 0.655 \\
\hline HER4 & Interesting traditions & & & .778 & & & & 0.695 \\
\hline HER3 & Artistic heritage & & & .761 & & & & 0.595 \\
\hline HER2 & Pleasant urban landscape & & & .720 & & & & 0.592 \\
\hline \multirow{2}{*}{\multicolumn{2}{|c|}{ Eigenvalue: 1.801}} & \multicolumn{5}{|c|}{ \% of Variance Explained: 6.431} & & \\
\hline & & \multicolumn{5}{|c|}{$\%$ Cumulative variance: 60.123} & & \\
\hline ICT1 & Coverage of ICT's & & & & .870 & & .848 & 0.691 \\
\hline ICT2 & Adoption of ICT's in local & & & & .841 & & & 0.725 \\
\hline
\end{tabular}

Investigaciones Turísticas

$N^{\circ} 14$, julio-diciembre 2017, pp. 1-20 


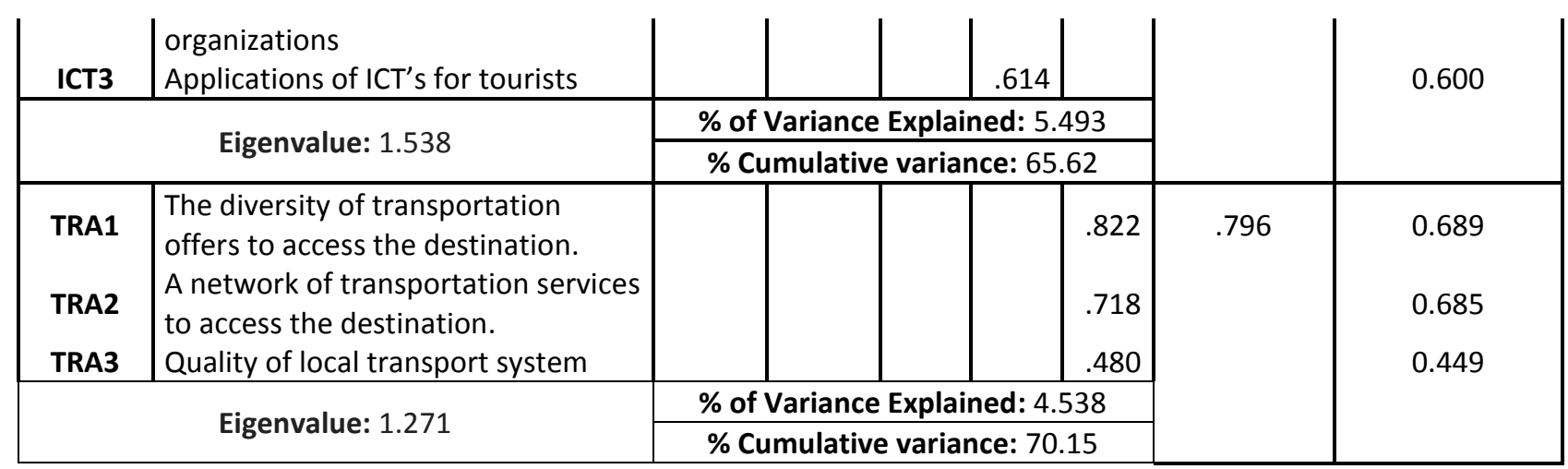

Table 7: Adequacy of the analysis of preserved factors and items

\begin{tabular}{|c|c|c|}
\hline \multicolumn{2}{|c|}{ Measures of adequacy of analysis } & Tourists \\
\hline \multicolumn{2}{|c|}{ Kaiser-Meyer-Olkin measure of adequacy of sampling } & 0.920 \\
\hline \multirow{3}{*}{ Bartlett's Sphericity Test } & Chi-square Approximated & 5416.97 \\
\cline { 2 - 3 } & Degrees of freedom & 378 \\
\cline { 2 - 3 } & Significance & 0.000 \\
\hline \multicolumn{2}{|c|}{ Minimum Eigenvalue } & 1.271 \\
\hline \multicolumn{2}{|c|}{ Variance Explanation } & $63.90 \%$ \\
\hline
\end{tabular}

\section{DESCRIPTIVE ANALYSIS}

In table 8 we observe that the survey's higher scores are for Destination Marketing \& Attractions with an average evaluation of 4.53 on the Likert's scale of 5 points, which can be considered a very assertive outcome. The lowest grades go to Destination Management \& Security, with a mean of 4.02, not an extremely negative result. On the affirmative side the best results go to brand awareness (IMA1), natural beauty (NAT 1), positive word of mouth (IMA7), quality of attractions (ATR1) and value of cultural heritage (HER1); this make much sense: Cancun is a very well-known world-class resort, with its mixed offer of Mayan legacy and beautiful beaches.

In the down side, the results on the Destination Management \& Security's factor reflect the serious national problem of crime, insecurity and impunity, especially in the items referred to trustworthiness of local population (SEC2), political stability (DM4), respect for laws and regulations (DM 2) and feeling of safety (SEC 1). Structural problems in quality of local transportation systems are reflected in the item TRA3; the similarity of results in the ICT's, and Transport variables draw the attention. Considering the standard deviation, with the exception of the Destination's Management \& Security factor, the values are smaller than 1 , with averages between 0.90 and 0.93 , confirming the data's reliability. The ratings on the retained variables reflect a destination's positive perception by the surveyed sample. 
Table 8: Descriptive results

\begin{tabular}{|c|c|c|c|c|c|c|c|}
\hline \multicolumn{2}{|c|}{ Destination Image and Attractions } & \multirow{2}{*}{\begin{tabular}{c|} 
Mean \\
4.52
\end{tabular}} & \multirow{2}{*}{$\begin{array}{l}\text { SD } \\
0.98\end{array}$} & \multicolumn{2}{|r|}{ Heritage } & \multirow{2}{*}{$\begin{array}{l}\text { Mean } \\
4.54\end{array}$} & \multirow{2}{*}{$\begin{array}{c}\text { SD } \\
0.77\end{array}$} \\
\hline IMA3 & Positive destination image & & & HER1 & $\begin{array}{l}\text { Value of destination's } \\
\text { cultural heritage }\end{array}$ & & \\
\hline IMA4 & $\begin{array}{l}\text { Expectations prior to the visit } \\
\text { met. }\end{array}$ & 4.38 & 1.05 & HER4 & Interesting traditions & 4.30 & 0.97 \\
\hline IMA2 & Quality of visit experience. & 4.51 & 0.89 & HER3 & Artistic heritage & 4.20 & 1.01 \\
\hline NAT1 & Region's natural beauty & 4.72 & 0.72 & HER2 & Pleasant urban landscape & 4.36 & 0.90 \\
\hline IMA1 & Destination brand awareness & 4.79 & 0.73 & & Average & 4.35 & 0.91 \\
\hline IMA7 & Positive word of mouth & 4.62 & 0.87 & \multicolumn{2}{|c|}{$\begin{array}{c}\text { Information and Communications } \\
\text { Technologies }\end{array}$} & Mean & SD \\
\hline IMA5 & Preference for the destination & 4.26 & 1.07 & ICT1 & Coverage of ICT's & 4.29 & 0.92 \\
\hline IMA6 & Intention to return & 4.53 & 0.90 & ICT2 & $\begin{array}{l}\text { Adoption of ICT's in local } \\
\text { organizations }\end{array}$ & 4.37 & 0.84 \\
\hline ATR3 & Variety of tours & 4.47 & 0.87 & ICT3 & $\begin{array}{l}\text { Applications of ICT's for } \\
\text { tourists }\end{array}$ & 4.21 & 0.99 \\
\hline ATR1 & Quality of attractions & 4.58 & 0.81 & \multicolumn{2}{|r|}{ Average } & 4.29 & 0.92 \\
\hline \multicolumn{2}{|r|}{ Variety of recreation offer } & 4.47 & 0.93 & & & & \\
\hline & Average & 4.53 & 0.90 & & & & \\
\hline \multicolumn{2}{|c|}{ Destination Management and Security } & Mean & SD & \multicolumn{2}{|r|}{ Transport } & Mean & SD \\
\hline SEC2 & $\begin{array}{l}\text { Trustworthiness of local } \\
\text { population }\end{array}$ & 3.92 & 1.14 & TRA1 & $\begin{array}{l}\text { The diversity of } \\
\text { transportation offers to } \\
\text { access the destination. }\end{array}$ & 4.47 & 0.82 \\
\hline DM4 & $\begin{array}{l}\text { Political stability in the } \\
\text { destination. }\end{array}$ & 4.04 & 1.17 & TRA2 & $\begin{array}{l}\text { A network of } \\
\text { transportation services to } \\
\text { access the destination. }\end{array}$ & 4.25 & 1.00 \\
\hline SEC3 & Positive conditions of hygiene & 4.13 & 1.04 & TRA3 & $\begin{array}{l}\text { Quality of local transport } \\
\text { system }\end{array}$ & 4.12 & 0.97 \\
\hline \multirow{2}{*}{$\begin{array}{l}\text { DM2 } \\
\text { SEC1 }\end{array}$} & \multirow{4}{*}{$\begin{array}{l}\text { Respect for laws and } \\
\text { regulations } \\
\text { Feeling of safety } \\
\text { Cooperation among } \\
\text { organizations to foster tourism } \\
\text { Importance of tourism in the } \\
\text { destination }\end{array}$} & 3.96 & 1.12 & \multicolumn{2}{|r|}{ Average } & 4.28 & 0.93 \\
\hline & & 4.02 & 1.11 & & & & \\
\hline DM1 & & 4.14 & 1.01 & & & & \\
\hline DM3 & & 4.38 & 0.94 & & & & \\
\hline \multicolumn{2}{|r|}{ Average } & 4.08 & 1.07 & & & & \\
\hline
\end{tabular}


Image 1: Competitiveness factors perceived by tourists

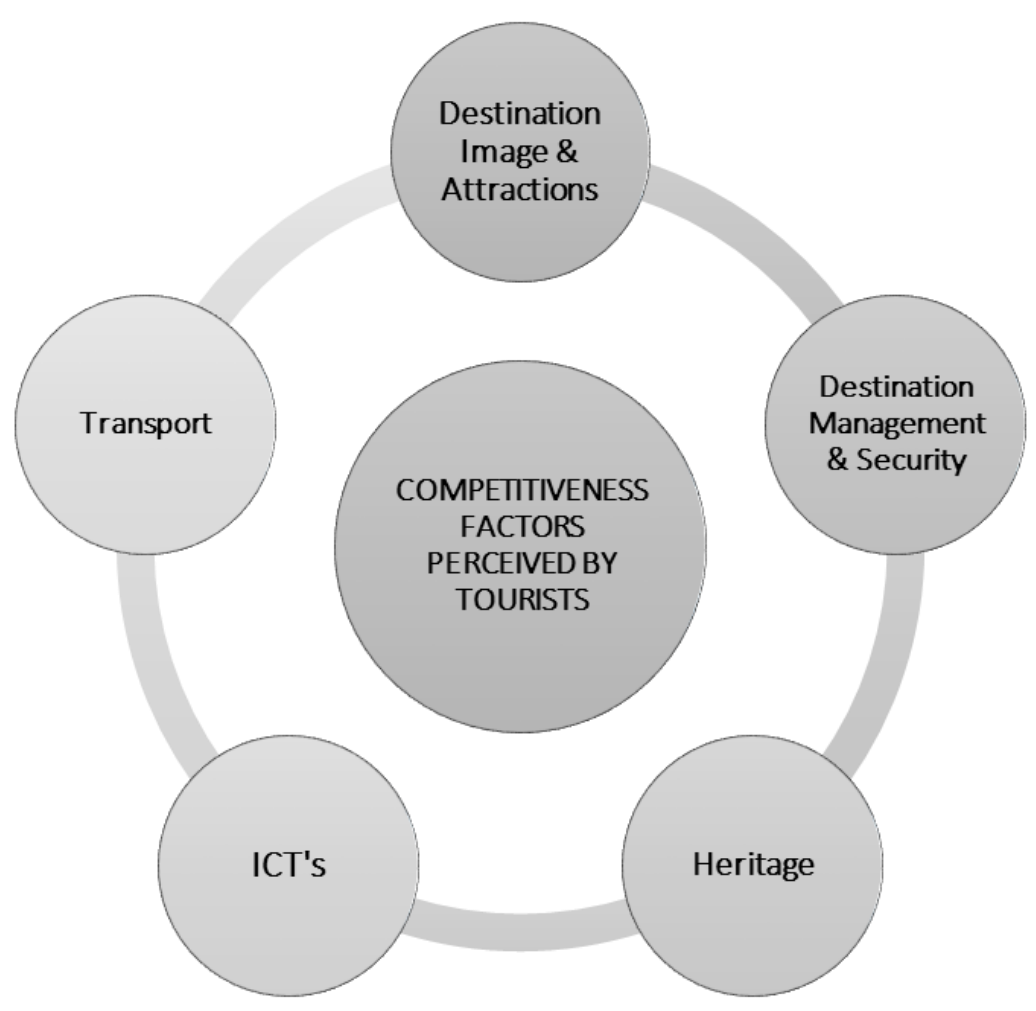

\section{DISCUSSION}

Therefore, from twelve factors related to tourist destination's competitiveness proposed originally, five were deleted along with the Exploratory Factor Analysis process: Price \& Value, Residents Quality of Life, Human Resources and Infrastructure. Another two, Attractions and Security, didn't disappear but were merged with other factors, plus one isolated item from the Nature-Sustainability aspect that was blended with the largest emergent variable. This leaves five remaining components: Destination Marketing \& Attractions, Destination Management \& Security, Cultural Heritage, ICT Adoption and Transportation (image 1). Remarkably, the most frequently mentioned destination competitiveness factor quoted in the academic literature, Nature \& Sustainability, (table 1) almost completely vanished.

The most important factor of destination competitiveness turned out to be Destination Marketing \& Attractions, on the meanings considered in the fields of consumer behavior, destination image, and branding (table 2), in a mixture with Attractions and natural beauty. This "super factor" concentrates eleven items from three original factors, an Eigenvalue of 12.78 and $44.30 \%$ of explained variance. The items with stronger load factor (0.874) were Positive Destination Image, in the sense mentioned by Crouch (2010) Huang \& Peng (2012) and Pike \& Mason (2010); expectations prior to the visit met (load factor 0.811) refer to satisfaction with the visit experience (Go \& Govers, 2010; Dupeyras \& MacCallum, 2013; Barros et al., 2011) and Quality of visit experience, as proposed by Claver et al. (2007), Dwyer \& Kim (2003) and Go \& Govers (2010). 
The item Destination brand awareness (load factor 0.775 ) belongs to the field of branding, as has been considered its influence in tourist competitiveness by Crouch (2010), Gomezelj \& Mihalic (2008) and Pike \& Mason (2010). The aspects Positive word of mouth, Preference for the destination and Intention to return, with load factors $0.771,0736$ and 0.726 , respectively, have to do with the loyalty of visitors to the place. It is interesting how the items related to the conative intentions of visitors lined neatly into the factor; these issues are analyzed by Caber et al. (2012), Hassan (2000) and Pike \& Mason (2010) in their works on competitiveness.

It draws attention the way the items belonging to the original Attraction aspect are tidily grouped at the bottom of the issues corresponding to the new factor, like if they were about to generate a different one (table 6); it must be said that Attractions are a subject mentioned more often in the tourism competitiveness literature than in marketing works. As its name implies, importance of attractions in destinations derives of their capacity to pull the visitors, confirmed in the number of authors that quote them as component of competitiveness: Andrades-Caldito et al. (2012), Cracolici \& Nijkamp (2008), Crouch (2010), Barros et al. (2011), Enright \& Newton (2004, 2005), Huang \& Peng (2012), Caber et al. (2012), Gomezelj \& Mihalic (2008) and Zhang et al. (2011).

The second new factor is a mixture of destination management and security, issues that relate directly to tourism policy; Destination management \& Security gathers seven items, four are referred to the first part of the binomial while three connect with the second portion. It has been mentioned that nowadays security is a major issue in Mexico, which might help to explain its presence in the remaining factor. Security at the tourist destination is a basic condition, a prerequisite to the existence of tourism activity in any place, maybe as essential as the presence of attractions. Likewise, is mentioned by many authors studying competitiveness (Andrades-Caldito et al., 2012; Blanke \& Chiesa, 2013; Caber et al., 2012; Crouch, 2010; Huang \& Peng, 2012; Rodrigues \& Carrasqueira, 2011 and Wu et al., 2012).

Destination management, in its relations with strategy, public policies and planning is also analyzed in an ample amount of competitiveness studies (Dupeyras \& MacCallum, 2013; Dwyer \& Kim, 2003; Gooroochurn \& Sugiyarto, 2005; Go \& Govers, 2010; Gomezelj \& Mihalic, 2008; Enright \& Newton, 2005; Huang \& Peng, 2012; Zhang et al., 2011 and Wu et al., 2012). What is different in the results of this study is the association of management with security, creating a new factor perceived by visitors. From a theoretical point of view, its emergence confirms the approaches of Presenza et al. (2005) and Ritchie \& Crouch (2005): they differentiate and separate the functions of administration and marketing in destinations.

Cultural heritage is another factor consistently quoted in the academic literature of destination competitiveness (Caber et al., 2012; Huang \& Peng, 2012; Andrades-Caldito et al., 2012; Dupeyras \& MacCallum, 2013; Dwyer \& Kim, 2003; Mazanec et al., 2007; Blanke \& Chiesa, 2013; Barros et al., 2011; Rodrigues \& Carrasqueira, 2011 and Carmichael, 2002). Actually, it has been demonstrated that heritage is more important than natural resources in terms of tourist attraction and competitiveness: Europe, the continent that received $51 \%$ of international tourists and $41 \%$ of its receipts in 2014 is mainly a cultural destination (World Tourism Organization, 2015).

The results of this study confirm the importance of cultural heritage in destination competitiveness. The component is located in third place among the five remaining and the 
four items related to the issue were retained, with load factors going from 0.720 to 0.820 ; the results for the variable in the descriptive scale were 4.35 , the second highest in the survey after Destination Image \& Attractions (tables 6 and 8). Although Cancun is basically a Sun and sea destination, the main factor of its international success is the mixture of quality beaches with the Mayan heritage of Yucatan; there are archaeological ruins in Cancun's hotel zone and is decorated with models of ancient sculptures. The town is located nearby antique Mayan cities like Chichén Itza, Tulum, Xcaret, and Cobá; many autochthonous traditions persist in the region.

Information and communications technology infrastructure is not one of the most quoted factors of destination competitiveness in academic literature; in a comparison with aspects like security, attractions, and cultural heritage, only a few consider it (Blanke \& Chiesa, 2013; Claver et al., 2007; Enright \& Newton, 2004, 2005; Gooroochurn \& Sugiyarto, 2005; Mazanec et al., 2007 and Wu et al., 2012). In the present survey, the three items proposed originally for this element persisted, with load factors going from 0.614 to 0.870 (table 6). The Travel \& Tourism Competitiveness Index 2009 treats all the pillars and subindices equally and flatly. Processing its data through Bayesian networks, Wu et al. (2012) identified causal relations among variables, finding that policy and regulations, air transport infrastructure, human resources, ICT's infrastructure, cultural resources, health, and hygiene are factors that influence the results presented in the ranking. The results of this study coincide with the findings of Wu et al. (2012) in that policy and regulations, ICT coverage, air transport infrastructure, and heritage are factors of destination competitiveness.

Transportation, the fifth factor remaining in the study, is not one of the components most frequently mentioned in the field's literature; besides, there are different approaches: some of the works revised refer to air transport infrastructure. Another one analyzes international transport and some others focus on public transportation (Blanke \& Chiesa, 2013; Caber et al., 2012; Huang \& Peng, 2012, Wu et al., 2012). Our study considered transportation in general; the three items proposed were retained, although Quality of local transport system shows one of the smallest load factors in the survey $(0.480$, table 6$)$.

At the national level, it can be said that Cancun's transportation infrastructure is advanced: the city has the second most important airport in the country, second only to Mexico City, but receiving more international passengers, with connections to The Americas and Europe; it has several motorways communicating with the main cities in the peninsula, substantial presence of rental car agencies, ferryboats, a large fleet of taxis and 24 hours bus service; most of the visitors, national and international, arrive flying.

\section{CONCLUSION}

The review of contemporary academic literature in the field of competitiveness of tourist destinations showed a wide dispersion among authors in terms of objects and subjects of study, methodologies, indicators, and factors. Trying to reduce the range, twelve competitiveness components were chosen among the most frequently mentioned in academic literature to perform an Exploratory Factor Analysis. The application of the method reduced the number of factors from twelve to five, although seven of them did not disappear, but two regrouped. 
The elimination of Nature, sustainability, Price - Value, Human Resources, Residents quality of life and Infrastructure through an Exploratory Factor Analysis process does not necessarily mean that these factors do not affect tourist destinations' competitiveness; it might also mean that they are not considered or perceived by tourists.

The identification of five tightly integrated factors represents an important advance in understanding the perception of tourism competitiveness. Among the main findings of this study are the elimination of the environmental sustainability component and the perception by visitors of differences between destination's management and marketing, as proposed by Presenza et al. (2005) and Ritchie \& Crouch (2005). The study as well confirms the findings of Wu et al. (2012) on the importance of policies and regulations, air transport infrastructure, cultural resources and coverage of ICT as factors influencing competitiveness.

The study was applied to a sample of Mexican tourists in a national sun and sea destination. It can be replicated in other types of destinations and tourists of different nationalities to confirm its results. It is as well advisable to investigate the perceptions of other types of stakeholders not included yet in studies on the subject, like workers in the hospitality industry and host population. The results and conclusions, by now, are referred to Mexican visitors; it would be interesting and valuable for the study of competitiveness to identify the factors noticed by several market segments or travelers of different nationalities over the same destination. Likewise, another opportunity for research refers to a deeper analysis of the descriptive results, which we are not performing in this paper due to extension limitations. The next logical step to advance the understanding of the subject would be the performance of a confirmatory factor analysis based on the five aspects of tourist destination's competitiveness identified in this study.

As managerial implications, tourism entrepreneurs and executives of destination management offices could use the study's results to act on the factors of competitiveness perceived directly by tourists in order to improve their performance. Studying different tourists segments or nationalities will provide them with the knowledge to improve the competitiveness according to their preferences and characteristics.

\section{REFERENCES}

ABC (1974). Cierre de hoteles en la provincia de mayor densidad de alojamientos turísticos. $A B C, 09 / 05 / 1974,59$.

Agarwal, S. (2002). Restructuring seaside tourism: The Resort Lifecycle. Annals of Tourism Research, 29(1), 25-55.

Andrades-Caldito, L., Sánchez-Rivero, M. \& Pulido-Fernández, J. (2013). Differentiating Competitiveness through Tourism Image Assessment: An Application to Andalusia. Journal of Travel Research, 52(1), 68- 81.

Barros, C., Botti, L., Peypoch, N., Robinot, E. \& Solonandrasana, B. (2011). Performance of French destinations: Tourism attraction perspectives. Tourism Management, 32(1), 141 146.

Blanke, J., Chiesa, T. \& Herrera, E. (2009). The Travel \& Tourism Competitiveness Index 2009: Measuring sectoral drivers in a downturn. In Blanke, J. \& Chiesa, T. (Eds.), The Travel \& Tourism Competitiveness Report 2009 (3-26). Geneva: World Economic Forum. 
Blanke, J. \& Chiesa, T. (Eds.). (2013). The Travel \& Tourism Competitiveness Report 2013. Geneva: World Economic Forum.

Bornhorst, T., Brent Ritchie, J. \& Sheehan, L. (2010). Determinants of tourism success for DMOs \& destinations: An empirical examination of stakeholders' perspectives. Tourism Management, 31, 572-589.

Botti, L. \& Peypoch, N. (2013). Multi-criteria ELECTRE method and destination competitiveness. Tourism Management Perspectives, 6, 108-113.

Buhalis, D. (2000). Marketing the competitive destination of the future. Tourism Management, 21, 97-116.

Caber, M., Albayrak, T. \& Matzler, K. (2012). Classification of the destination attributes in the content of competitiveness (by revised importance-performance analysis). Journal of Vacation Marketing, 18(1), 43-56.

Carmichael, B. (2002). Global Competitiveness and Special Events in Cultural Tourism: The Example of the Barnes Exhibit at the Art Gallery of Ontario, Toronto. The Canadian Geographer, 46(4), 310-324.

Cho, D. \& Moon, H. (2013). From Adam Smith to Michael Porter: Evolution of Competitiveness Theory. Singapore: World Scientific Publishing Co. Pte. Ltd.

Claver-Cortés, E., \& Pereira-Moliner, J. (2007). Competitiveness in mass tourism. Annals of Tourism Research, 34(3), 727-745.

Cracolici, M., Nijkamp, P. \& Rietveld, P. (2008). Assessment of tourism competitiveness by analyzing destination efficiency. Tourism Economics, 14, 325-342.

Cracolici, M. \& Nijkamp, P. (2008). The attractiveness and competitiveness of tourist destinations: A study of Southern Italian regions. Tourism Management, 30(3), 336-344.

Croes, R. \& Rivera, M. (2010). Testing the empirical link between tourism and competitiveness: evidence from Puerto Rico. Tourism Economics, 16(1), 217-234.

Croes, R. (2010). Measuring and Explaining Competitiveness in the Context of Small Island Destinations. Journal of Travel Research, 50(4), 431-442.

Crouch, G. \& Ritchie, J. (1999). Tourism, competitiveness and societal prosperity. Journal of Business Research, 44, 137-152.

Crouch, G. (2010). Destination Competitiveness: An Analysis of Determinant Attributes. Journal of Travel Research, 50, 27-45.

De Vellis, R. (2011). Scale Development: Theory and applications. USA: Sage.

Dupeyras, A. \& Maccallum, N. (Eds.). (2013). Indicators for Measuring Competitiveness in Tourism: A Guidance Document. OECD Tourism Papers, 2013/02, OECD Publishing. Retrieved from http://dx.doi.org/10.1787/5k47t9q2t923-en

Dwyer, L., Cvelbar, L., Edwards, D. \& Mihalic, T. (2012). Fashioning a destination tourism future: The case of Slovenia. Tourism Management, 33, 305-316.

Dwyer, L. \& Kim, Ch. (2003). Destination Competitiveness: Determinants and Indicators. Current Issues in Tourism, 6(5), $369-414$.

Enright, M. \& Newton, J. (2004). Tourism Destination Competitiveness: A Quantitative Approach. Tourism Management, 25(6), 777-788.

Enright, M. \& Newton, J. (2005). Determinants of Tourism Destination Competitiveness in Asia Pacific: Comprehensiveness and Universality. Journal of Travel Research, 43, 339350. 
Faulkner, B., Oppermann, M. \& Fredline, E. (1999). Destination Competitiveness: An Exploratory Examination of South Australia's Core Attractions. Journal of Vacation Marketing, 5(2), 125-139.

Finch, H. (2006). Comparison of the performance of varimax and promax rotations: Factor structure recovery for dichotomous items. Journal of Educational Measurement, 43(1), $39-52$.

Gallarza, M., Saura, I. \& Garcia, H. (2002). Destination image: Towards a conceptual framework. Annals of Tourism Research, 29(1), 56-78.

Go, F. \& Govers, R. (2000). Integrated quality management for tourist destinations: a European perspective on achieving competitiveness. Tourism Management, 21, (1), 7988.

Gobierno del Estado de Quintana Roo. (2014). Indicadores Turísticos 2013, Secretaría de Desarrollo Turístico.

Recovered

http://sedetur.qroo.gob.mx/estadisticas/indicadores/Indicadores\%20Turisticos\%202013 .pdf.

Gomezelj, D. \& Mihalic, T. (2008). Destination competitiveness - Applying different models, the case of Slovenia. Tourism Management, 29, 294-307.

Gooroochurn, N. \& Sugiyarto, G. (2005). Competitiveness indicators in the travel and tourism industry. Tourism Economics, 11, (1), 25-43.

Hair, J., Tatham, R., Anderson, R. \& Black, W. (2006). Multivariate Data Analysis. USA: Pearson Prentice Hall.

Hassan, S. (2000). Determinants of market competitiveness in an environmentally sustainable tourism industry. Journal of Travel Research, 38, 239-245.

Huang, J. \& Peng, K. (2012). Fuzzy Rasch model in TOPSIS: A new approach for generating fuzzy numbers to assess the competitiveness of the tourism industries in Asian countries. Tourism Management, 33, 456-465.

Huybers, T. \& Bennett, J. (2003). Environmental Management and the Competitiveness of Nature-Based Tourism Destinations. Environmental and Resource Economics, 24, 213233.

Li, H. \& Huang, L. (2010). The competitiveness of Hong Kong's travel industry: a dynamic shift-share analysis. Tourism Economics, 16(3), 665-684.

Maccallum, R., Widaman, K., Zhang, S. \& Hong, S. (1999). Sample size in factor analysis. Psychological Methods, 4(1), 84-99.

Mangion, M., Cooper, C., Cortés-Jimenez I. \& Durbarry, R. (2012). Measuring the effect of subsidization on tourism demand and destination competitiveness through the AIDS model: an evidence-based approach to tourism policymaking. Tourism Economics, 18(6), 1251-1272.

Mazanec, J., Wöber, K. \& Zins, A. (2007). Tourism Destination Competitiveness: From Definition to Explanation? Journal of Travel Research, 46, 86-95.

Medina-Muñoz, D., Medina-Muñoz, R. \& Chim-Miki, A. (2013). Tourism competitiveness assessment: the current status of research in Spain and China. Tourism Economics, 19(2), 297-318.

Molina-Azorin, J., Pereira-Moliner, J. \& Claver-Cortés, E. (2010). The importance of the firm and destination effects to explain firm performance. Tourism Management, 31, 22-28.

Osborne, J. \& Costello, A. (2005). Best practices in exploratory factor analysis: Four recommendations for getting the most from your analysis. Practical assessment, 
research \& evaluation, 10(7), 1-9. Retrieved from http://pareonline.net/getvn.asp?v=10\&n=7.

Osborne, J. (2015). What is Rotating in Exploratory Factor Analysis? Practical Assessment, Research \& Evaluation, 20(2), 1-7. Retrieved from http://pareonline.net/getvn.asp?v=20\&n=2.

Pike, S. \& Mason, R. (2010). Destination competitiveness through the lens of brand positioning: the case of Australia's Sunshine Coast. Current Issues in Tourism, 4(2), 169182.

Pike, S. (2002). Destination image analysis-a review of 142 papers from 1973 to 2000. Tourism Management, 23(5), 541-549.

Porter, M. (1993). The competitive advantage of nations. USA: Harvard Business School Management Programs.

Porter, M. (1998). Competitive Strategy: Techniques for Analyzing Industries and Competitors. USA: Free Press.

Presenza, A., Sheehan, L. \& Ritchie, J. B. (2005). Towards a model of the roles and activities of destination management organizations. Journal of Hospitality, Tourism and Leisure Science, 3(1), 1-16.

Ritchie, J. \& Crouch, G. (1993), Competitiveness in international tourism: A framework for understanding and analysis. World Tourism Education and Research Centre, University of Calgary. Retrieved from

http://scholar.google.com/scholar?as q=\&as epq=Competitiveness\%20in\%20internatio nal\%20tourism\%3A\%20A\%20framework\%20for\%20understanding\%20and\%20analysis\& as occt=title\&as sauthors $=+$ \&as $y l o=\& a s$ yhi=\&as $\mathrm{sdt}=1$.\&as $\mathrm{sdtp}=0$ \&as $\mathrm{sdtf}=$ \&as $\mathrm{s}$ $\mathrm{dts}=22 \&$

Ritchie, J. \& Crouch, G. (2005). The competitive destination. A sustainable tourism perspective. USA: CABI Publishing.

Rodrigues, L. \& Carrasqueira, H. (2011). Análisis del desempeño competitivo de los destinos turísticos balnearios. El caso de Algarbe versus el Sur de España. Estudios y Perspectivas en Turismo, 20(4), 855-875.

Secretaría de Turismo. (2014). Compendio Estadístico del Sector Turismo de 2013. DATATUR. Recovered from http://www.datatur.beta.sectur.gob.mx/.

Tabachnick, B. \& Fidell, L. (2012). Using Multivariate Statistics. USA: Pearson.

Velicer, W. \& Jackson, D. (1990). Component Analysis Versus Common Factor-Analysis Some Further Observations. Multivariate Behavioral Research, 25(1), 97-114.

Vu, J. \& Turner, L. (2011). Shift-share analysis to measure arrivals competitiveness: the case of Vietnam, 1995-2007. Tourism Economics, 17(4), 803-812.

Webster, C. \& Ivanov, S. (2014). Transforming competitiveness into economic benefits: Does tourism stimulate economic growth in more competitive destinations? Tourism Management, 40, 137-140.

World Economic Forum \& IMD International. (1994). The World Competitiveness Report 1994. Lausanne, Switzerland.

World Tourism Organization. (2015). Tourism Highlights, 2014 Edition. Recovered from http://www.unwto.org/facts/eng/highlights.htm.

Wu, W., Lan, L. \& Lee, Y. (2012). Critiquing the World Economic Forum's concept of destination competitiveness: A further analysis. Tourism Management Perspectives, 4, 198-206.

Investigaciones Turísticas

$\mathrm{N}^{\circ}$ 14, julio-diciembre 2017, pp. 1-20 
Zhang, J. \& Jensen, C. (2007). Comparative Advantage. Explaining Tourism Flows. Annals of Tourism Research, 34(1), 223-243.

Zhang, H., Gu, C., Gu, L. \& Zhang, Y. (2011). The evaluation of tourism destination competitiveness by TOPSIS \& information entropy - A case in the Yangtze River Delta of China. Tourism Management, 32, 443-451. 